\title{
Princip komparability a možnosti jeho aplikace při komparaci anglosaského a kontinentálního systému právní kultury
}

$\mathbf{N}$ o p, M.*

NOP, M.: Princip komparability a možnosti jeho aplikace při komparaci anglosaského a kontinentálního systému právní kultury. Právny obzor, 104, 2021, č. 2, s. 170 - 188.

The principle of comparability and the possibilities of its application in the comparison of the Anglo-Saxon and European continental systems of legal culture. The aim of this paper is to show the possibilities and limits of the comparison of AngloSaxon and European continental legal cultures. In the work, it is clarified the content of the principle of comparability. Furthermore, the different historical foundations of both systems are discussed and the role of history for macrocomparative legal analysis is emphasized.. The role of general philosophy in the typification of legal cultures is highlighted as well. The current dialogue between contemporary analytical and continental philosophies is reflected in the analysis of the typical way of legal thinking in the observed legal cultures. The analysis is therefore based on the application of elements of general culture to the culture of the legal system. The possibilities of such an application are demonstrated in the analysis of the way of interpretation of normative legal acts in both cultures. The similarities and differences of the methodology of interpretation of law in the diachronic perspective are also analysed. It is argued that the historical differences between Anglo-Saxon and European continental legal cultures concern not only private law but also public law, as they are based on a more general thought base typical of each culture. Methodologically, the work is based on sociological and historical forms of comparison.

Key words: comparability, Anglo-Saxon law, common law, European continental law, legal culture, philosophy of law, interpretation of law

\section{Úvod $^{1}$}

Tento text si klade za cíl především osvětlit, jakým způsobem lze zkoumat divergenci a konvergenci anglosaského a kontinentálního systému právní kultury. Tato otázka je zvláště aktuální vzhledem k odchodu Spojeného království z Evropské unie. Text se proto zaměřuje na anglosaské právo v původním smyslu, tedy zejména na právo Anglie a Walesu, a nezahrnuje další, z anglického systému odvozené právní rády. Ze stejného důvodu je v analýze proměny ostrovního práva akcentován vliv acquis communautaire a stranou je ponechán významný vliv částečné inkorporace Evropské úmluvy o ochraně lidských práv a základních svobod do britského právního řádu prostřednictvím tzv. $H u$ man Rights Act 1998 (zákona o lidských právech z roku 1998) a prostřednictvím příslušné legislativy ve Skotsku a ve Walesu.

\footnotetext{
* JUDr. Mgr. Michal N o p, externí doktorand Katedry teorie práva a právních učení Právnické fakulty UK.

1 Tento př́spěvek vznik1 v rámci plnění projektu Specifického vysokoškolského výzkumu (SVV) Univerzity Karlovy č. 260494 „Integrujicí úloha lidských práv v současném právu“.
} 


\section{Podstata právních kultur a možnost jejich komparace}

Komplexní právní systém mohl vzniknout až v rámci civilizace, chápané v singulárním pojetí. V jednotném čísle můžeme civilizaci chápat jako proces „dějinně univerzálního vývoje lidských schopností' “. ${ }^{2}$ Civilizace, chápaná jako pojem užívaný v množném čísle, jsou rozsáhlé a dlouhodobé společenské formace specifického druhu, které mají své specifické civilizační vzorce. „Různost mnohorozměrných civilizačních vzorců se složkami kulturními, politickými a ekonomickými - je neoddělitelná od transformace, z níž se zrodily státnost, městský život a písemnictví." ${ }^{\text {”3 }}$

Při používání pojmu „civilizace“v plurálu považuji oblast anglosaské a kontinentální kultury za součást jedné křest’ansko-židovské civilizace, která má výrazné společné prvky, odlišné např́ḱlad od islámské civilizace. „Civilizace jsou, podle Durkheima a Mausse, seskupení společností spojených sdíleným kulturním prostředím (milieu moral) a transfery rozmanitého druhu, přičemž je třeba diferencovat mezi odlišnými možnostmi a modalitami transferu jak v různých sférách společenského života, tak na úrovni různých civilizačních celků “4 ${ }^{\mathrm{V}} \mathrm{V}$ tomto pojetí může být koncept civilizace považován za „rodiny společnosti'“. ${ }^{5}$ Civilizační celky tedy jsou z hlediska třídění systémů na vyšší pozici než kultury, které jsou rozlišovány uvnitř a v rámci jednoho civilizačního celku.

Pro rozlišení jednoho systému právní kultury od druhého můžeme použít různá třídicí kritéria, v zásadě se ale jako kritéria používají prvky, které se v daném systému vyskytují dlouhodobě, jsou dostatečně význačné a odlišují jej od jiného právního systému. Proto se u komparatistů setkáváme s tříděním, které bere v úvahu sociální povahu právního systému a nezužuje komparaci na pouhé srovnávání právních norem.

Klasické třídění uživají například Zweigert a Kötz, kteří jako stylotvorná kritéria rozlišují: a) historické pozadí a vývoj systému; b) typický způsob právního myšlení; c) příznačné právní instituty; d) druhy právních pramenů v daném systému a způsob jejich interpretace; e) ideologii systému. ${ }^{6}$ Toto třídění lze považovat za holistické, nebot' v duchu Aristotelovy teze, že ,,celek skládajici se z částí, který má svou vlastni podstatu, je zjevně více než souhrn svých části "7, se vyhýbá redukcionistické komparaci pozitivního práva a snaží se pátrat po př́činách a podstatě systému. Ač se může v holistickém systému jevit nalézání jednotlivých kauzálních vztahů jako problematické, lze při komparaci velkých myšlenkových celků považovat holistický př́stup za metodologicky př́ihodnější než koncept redukcionistický. Nejen proto, že velký systémový komplex právní kultury je obtížné zredukovat tak, aby redukovaný obraz odrážel realitu, ale též z toho důvodu, že v dnešní globalizované době, v níž jsou jednotlivé právní instituty do právních ráå

${ }^{2}$ ÁRNASON, J. P. Civilizační analýza: Evropa a Asie opět na rozcestí. Praha, 2009, s. 36.

${ }^{3}$ Ibidem, s. 44.

${ }^{4}$ ÁRNASON, J. P. Max Weber jako klasik civilizační analýzy: komparativní pohledy na souhru kultury a moci. Sociológia, 2012, roč. 44, č. 5, s. 548-563, s. 555.

${ }^{5}$ ÁRNASON, J. P. Civilizations in dispute: historical questions and theoretical traditions. Leiden, 2003, s. 296.

${ }^{6}$ ZWEIGERT, K. - KÖTZ, H. Einführung in die Rechtsvergleichung. Band 1: Grundlagen. 3. Auflage. Tübingen, 1992, s. 73.

${ }^{7}$ ARISTOTELÉS - KREJČÍ, F. (ed.) Aristotelova Metafysika. Praha, 1927, s. 153, 8.6., [=1045a]. 
přebírány nejen z právních řádů př́buzných, ale též z jiných právních rodin, by pouhá komparace právních institutů pozitivního práva obtížně korespondovala se skutečností.

Pojem „systém právní kultury“, který je užit v názvu tohoto textu, podle mého názoru lépe než pojem „právní systém“ vystihuje fakt, že daný systém je zakotven v určité právní kultuře, že se tudíž při komparaci nejedná pouze o srovnání systémů pozitivního práva, ale že se srovnává právo, které je chápáno sociologicky, a v úvahu jsou brány také způsoby myšlení, které jsou typické pro daný systém.

Myšlenka existence právní kultury v sobě zahrnuje především předpoklad, že právo je součástí širší kultury. Tato idea vychází z toho, že pouhá znalost právních pravidel není dostatečná pro pochopení práva $\mathrm{v}$ dané kultuře. Předpokládá se nutnost zkoumání ustálené praxe, tradic, zvyklostí či implicitně obsažených předpokladů, které teprve umožní porozumět danému právu.

Právní řád je utvářen v rámci určité kultury a na jejím základě. Projevem kultury a zároveň jejím hybatelem je nepochybně filosofie. Do právních řádů jednotlivých zemí se tedy promítá způsob nazírání na svět v té které kultuře. Akademické rozbory v oblasti právního myšlení se shodují na možnosti vést smysluplnou dělicí linii mezi anglosaskou a kontinentální právní filosofií. ${ }^{8}$ Také v oblasti obecné filosofie je za svébytný směr evropského duchovního vývoje, který je zcela jiného druhu než směr francouzsko-nizozemský a německý, považováno anglické filosofické myšlení. ${ }^{9}$ Přirozeně se v obou systémech vyskytují myslitelé, kteří mohou být více ovlivněni myšlenkami dominujícími $\mathrm{v}$ jiné kultuře, vypovídající je ovšem sledování způsobů myšlení, které jsou v dané společnosti dlouhodobě převažující.

V komparatistické literatuře se často setkáme s tím, že jsou vybrány určité části právního systému, které jsou považovány za takové elementy, prostřednictvím nichž lze demonstrovat blízkost právních kultur. Výběr takových komponent je však do značné míry subjektivní. Pro dosažení vyšší míry objektivity by bylo potřebné určení kritéria, na základě něhož by bylo lze rozhodnout, které prvky určují podstatu jednotlivých kultur. To se jeví při existenci různých definic kultur a obvyklé vágnosti pojmu „kultura“ jako značně obtížné. Na vysoké úrovni obecnosti však lze za stylotvorné kritérium považovat převládající myšlenkové tradice. Na nižší úrovni obecnosti lze snad účelně komparovat právní instituty, pokud splňují podmínku dostatečné univerzálnosti. Typově se jedná o instituty manželství, vlastnictví či dědění. Lze tak souhlasit s V. Knappem, že v právní makrokomparatistice lze stylotvorné prvky, byt' nedefinovatelné a empiricky zjišstované, jako rozlišovací a třídicí kritérium použít, nebot' ,lepší intuitivně daná kritéria než žádná". ${ }^{10}$

Aby mohly být prvky porovnány, musí být podřízeny principu komparability (srovnatelnosti), který znamená, že racionálně lze srovnávat pouze jevy stejného řádu, jevy

\footnotetext{
${ }^{8}$ Srov. např. KUKLÍK, J. - SELTENREICH, R. Dějiny angloamerického práva. 2. vyd. Praha, 2011, s. 445. Rovněž KRSKOVÁ, A. Stát a právo v evropském myšlení. 2. vyd. Praha, 2005, s. 278-279.

${ }^{9}$ Srov. literaturu shrnující způsoby myšlení v jednotlivých kulturách, jak je uvedena např. in STÖRIG, H. J. Malé dějiny filozofie. Praha, 1999, s. 250, nebo KRSKOVÁ, A. Stát a právo v evropském myšlení, s. 278-279.

${ }^{10}$ KNAPP, V. Velké právni systémy. (Úvod do srovnávaci právní vědy.) Praha, 1996, s. 23.
} 
souměřitelné. Z obecnějšího pohledu je tedy sice srovnatelné všechno se vším, nicméně racionální srovnatelnost musí ukazovat takový vztah srovnávaných předmětů, který komparací umožňuje dospět k rozumné míre abstrakce. ${ }^{11}$ Komparabilita v sobě apriorně implikuje podobnost, která může být pojímána jako škála identity, jejíž póly mohou být z jistého hlediska tvořeny na jedné straně totožností všech srovnávaných vlastností a na straně druhé absencí jakékoli stejné vlastnosti, znamenající maximální rozdílnost. ${ }^{12}$ Knapp na druhou stranu považuje za podobnost pouze takový př́pad, kdy alespoň jeden prvek obsahu srovnávaných pojmů je shodný a alespoň jeden prvek jejich obsahu není shodný. ${ }^{13}$ Maximální rozdílnost, kdy ani jeden prvek obsahu srovnávaných prvků není shodný, by tedy podle Knappa již nespadala do kategorie podobnosti. Pro praktický výsledek porovnání právních kultur však exaktní vymezení není zásadní, a to především vzhledem k vysoké obecnosti pojmu „právní kultura“.

Při komparaci právních kultur by měla jejich podobnost nabírat pravděpodobně podobu analogie, chápanou jako podobnost různých systémů s ohledem na určité vlastnosti, strukturu či funkce. ${ }^{14}$ Odlišnost právních kultur se pak může nepochybně projevovat v odlišné struktuře či rozdílných vlastnostech zkoumaného systémového prvku. Při komparaci samotných právních institutů na druhou stranu nelze presumovat odlišnost funkcí, ale naopak lze předpokládat a priori danou funkcionální analogii, jejíž identifikace nás přivedla právě $\mathrm{k}$ tomu, že právní instituty můžeme považovat za racionálně komparabilní.

V komparatistice německé a francouzské často převládal pozitivistický přístup ke srovnávání právních řádů, což je pojetí, u něhož komparatistika ulpívala na slovním výrazu právní normy, aniž by se starala o metanormativní skutečnosti. ${ }^{15}$ Opačný postoj je vlastní sociologickému prístupu k právu.

Srovnávací metodu ve své sociologické podobě je možno aplikovat při komparaci právních institutů, tj. ucelených souborů právních norem, které upravují společenské vztahy vnímané jako celek, následujícím způsobem: právní instituty budou apriorně stanoveny; poté bude zkoumáno, jak jsou předmětné instituty v dané právní kultuře upraveny. Takto získané poznatky budou komparovány. Nejprve se přitom využije analytický postup, kdy právní instituce budou dekomponovány na jednotlivé prvky, které pak budou srovnány, a následně postup syntetický, při kterém dojde k naznačení vztahů mezi jednotlivými prvky a utvoření představy o daném právním institutu v příslušné právní kultuře. Použití této metody má za cíl odhalit a vědecky zdůvodnit podstatné rozdíly a podobnosti mezi srovnávanými právními kategoriemi.

V př́ípadě mapování podobnosti a rozdílnosti právních kultur bude typické použití komparatistiky multilaterální, kdy budou poznatky získávány srovnáváním více než dvou prvků, a to v podobě, kterou mají ve stejném čase (zkoumání bude synchronické).

${ }^{11}$ Ibidem, s. 5.

${ }^{12}$ LINHART, J. - VODÁKOVÁ, A. - PETRUSEK, M. (eds.) Velký sociologický slovník. Praha, 1996, s. 502.

${ }^{13}$ KNAPP, V. Velké právni systémy. (Úvod do srovnávaci právní vědy.), s. 5.

${ }^{14}$ LINHART, J. - VODÁKOVÁ, A. - PETRUSEK, M. (eds.), Velký sociologický slovník, s. 53.

${ }^{15}$ KNAPP, V. Velké právni systémy. (Úvod do srovnávací právní vědy.), s. 36. 
Takové bádání slouží pro odlišení existence systémů více právních kultur v jedné době. Za relevantní lze považovat také užití komparace historické (diachronické) ve smyslu srovnání současného práva určitého státu (či okruhu států) s jeho (či jejich) právem minulým, nebot' taková komparace slouží pro mapování trendů, a tedy zjištění, zda dochází mezi systémy k divergenci či konvergenci.

Komparujeme-li v makroperspektivě právní kultury, měl by být př́stup sociologický, nebot' právní kultury lze chápat jako společenské normativní systémy, jež ve společnosti vznikají, vyvíjí se a působí. Zkoumání je tedy vhodné podrobit také ideologická východiska, z nichž jednotlivé prvky právních kultur vycházejí. Sociologická metoda je na místě i tam, kde je sledován vliv př́stupu určitého státu k mezinárodní či nadnárodní organizaci na její činnost, a naopak též zpětný vliv takové organizace na právní rády členských států.

\section{Význam historických základů pro makrokomparaci systémů právní kultury}

Makrokomparace dvou systémů našla své místo již v pracích Aristotela, který úspěšně využil srovnávací metodu pro typologii politických systémů. ${ }^{16} \mathrm{~V}$ oblasti vlastního srovnávání právních řádů je za průkopníka považován Ch. L. de Montesquieu. ${ }^{17}$ Montesquieu se domnívá, že správné právo, tj. takové které odpovídá povaze národa, lze odvodit z vnějších činitelů, včetně geografických poměrů. „Zákony musí být v takovém vztahu k povaze a k zásadám vlády, která je ustavena nebo která má být ustavena, že bud' tuto vládu tvoří (tak je to u práva veřejného), nebo že ji udržují (to je u práva soukromého). Zákony musí míti určitý vztah $\mathrm{k}$ fysické povaze kraje, k podnebí studenému, horkému nebo mírnému; k povaze půdy, $\mathrm{k}$ její poloze, $\mathrm{k}$ její rozlehlosti, ke způsobu života národů (rolnickému, loveckému nebo pasteveckému). Musí také míti určitý vztah ke stupni svobody, kterou chce dáti ústava, $\mathrm{k}$ náboženství obyvatelů, $\mathrm{k}$ jejich povaze, $\mathrm{k}$ jejich bohatství, k jejich počtu, $\mathrm{k}$ jejich stykům, k jejich mravům, k jejich způsobům. Konečně mají určitý vztah mezi sebou: $\mathrm{k}$ svému vzniku, $\mathrm{k}$ cíli, který si zákonodárce stanovil, k řádu věcí, nad nimiž budou vládnouti. " 18 Použijeme-li ideje Montesquieuho na možnost srovnání anglosaského a kontinentálního typu právní kultury, můžeme konstatovat, že aplikace jím zastávaného geografického determinismu ve svém důsledku znamená také to, že ostrovní charakter Británie utváŕí zvláštní typologii její právní kultury.

Z dnešního pohledu považuji za správný Montesquieuho předpoklad, že v počátečních fázích vývoje člověka a společnosti geografické prostředí determinovalo jak existenci člověka, tak různé typy osobností, a mělo tudíž svůj vliv na odlišný vývoj lidských společností včetně právní kultury. S rozvojem civilizace a obchodu lze usuzovat na to, že se vliv geografického prostředí na typ právní kultury postupně snižoval. Nelze však říci, že by byl zanedbatelný a z tohoto hlediska lze ocenit př́nos Montesquieuho i dnes.

\footnotetext{
${ }^{16}$ ARISTOTELÉS. Politika. 2. vyd. Praha, 1998, s. 65-105.

${ }^{17}$ ŠTEFANOVIČ, M. Všeobecná porovnávacia právoveda. Bratislava, 1992, s. 58.

${ }^{18}$ MONTESQUIEU, Ch. L. de S. O duchu zákonů. Dobrá Voda, 2003, s. 39.
} 
Napojení právní kultury na obecné filosofické myšlení lze vysledovat nejen na konstrukci celého právního řádu, ale i v konkrétnějších projevech myšlení u jednotlivých právních odvětví. Někdy se hovoří o tom, že dělicí čára mezi anglosaskou a kontinentální právní kulturou zasahuje hlavně do oblasti soukromého práva ${ }^{19}$ a je také pravdou, že metodické základy srovnávání jsou spojeny především s právem soukromým. ${ }^{20} \mathrm{~S}$ tím, jak postupuje europeizace a internacionalizace práva, dochází ovšem ve stále větší míře i k porovnávání práva veřejného. V souladu se svým pohledem na právní kulturu jakožto součást obecné kultury, která je formována jiným způsobem myšlení v každém ze sledovaných systémů, mám za to, že rozdíly mezi anglosaským a kontinentálním právním systémem jsou i ve sféře práva veřejného natolik výrazné, aby bylo možno také zde hovořit o odlišných právních kulturách. Ostatně i klasik právní komparatistiky René David vyzdvihl jako význačný rys anglického práva to, že „,anglické právo má výrazný procesně sporový charakter a jeho základy ovládá soudní řízení“21, tj. poukázal na výraznou odlišnost mezi právními kulturami, která se line napříč veřejným a soukromým právem. Stejně tak připomínal, že v Anglii se mezi veřejným a soukromým právem nerozlišuje. ${ }^{22}$ To by ovšem znamenalo, že pokud bychom se soustředili na komparaci toliko v oblasti soukromého práva, bude se jednat o vymezení dané pouze jednou právní kulturou, tedy tou, která „soukromé právo“ ve svém řádu rozlišuje, tj. kulturou kontinentální. Taková komparace pak nemůže být úplná a ani aproximativně objektivní.

Vycházím tedy z toho, že komparace mezi jednotlivými právními řády by byla přínosná ve všech právních odvětvích. Odlišné pojímání odvětví trestního práva v anglosaském a kontinentálním systému vysledoval J. Fenyk. Odlišnost nachází v samotné filosofické podstatě, v soupeření dogmatismu s pragmatismem, když dogmatismem rozumí „vytváření konzervativních kategorií, spojené s vírou v neměnnost uznávaných právních hodnot, a jejich aplikaci“ (pojetí kontinentální), zatímco pragmatismus spatřuje $\mathrm{v}$ „tvưrčím př́ístupu umocněném kriteriem užitečnosti, resp. potřebnosti““ (pojetí anglosaské). ${ }^{23}$

Takové rozdělení vychází z pozorování dlouhodobých rozdílů v myšlení obou kultur a odpovídá odlišnostem dominantních proudů v anglosaské a kontinentální filosofii. Anglosaské pojetí je svobodomyslnější než kontinentální, projevuje se v něm vyšší důvěra v kapitalismus, který se v anglosaské oblasti prosadil dřive. Toto anglosaské myšlení je také méně nedůvěřivé k postupným reformám. Naproti tomu kontinentální koncept byl vystavěn na bázi racionalismu a na víře, že rozum je všemocný. Eo ipso se podle něj mají

\footnotetext{
${ }^{19}$ Srov. např. ADAMOVÁ, K. - BĚLOVSKÝ, P. - FALADA, D. a kol. Dějiny evropského kontinentálního práva: vysokoškolská právnická učebnice. 3. uprav. vyd. Praha, 2010, s. 11.

${ }^{20}$ TSCHENTSCHER, A. Dialektische Rechtsvergleichung - Zur Methode der Komparistik im öffentlichen Recht. Juristen Zeitung, 2007, Jhrg. 62, Nr. 17, s. 807-816.

${ }^{21}$ DAVID, R. Anglické právo. Bratislava, 1972, s. 10.

${ }^{22}$ Ibidem, s. 16.

${ }^{23}$ FENYK, J. Kontinentální dogmatismus a anglosaský pragmatismus z pohledu základů trestní odpovědnosti. In GERLOCH, A. - MARŠÁLEK, P. (eds.) Zákon v kontinentálním právu: sborník príspěvků z mezinárodni vědecké konference „Misto a úloha zákona v kontinentálním typu právní kultury: tradice, současnost a vývojové tendence" (Praha 27. - 28. května 2004). Praha, 2005, s. 227.
} 
odstranit veškeré tradice a na základě racionálního plánu by se měla vytvořit vhodná společenská konstrukce. ${ }^{24}$

Stejné faktory přitom působí i na další odvětví soukromého i veřejného práva. Tak například v právu ústavním nalezneme zřetelné rozdíly ve způsobu utvoření ústav i jejich obsahu. Ústava Spojeného království vznikala postupně a její vznik spadá až k listině Magna Charta Libertatum z roku 1215. Britská ústava není tvořena jediným dokumentem, nadaným nejvyšší právní silou a její velká část je nepsaná, tvořená uznávanými pravidly a ústavními konvencemi. Nemá zřetelné kontury a nejsou dány jasné hranice mezi ústavním a správním právem. ${ }^{25}$ Formovala se historicky na základě postupně se utvářejícího politického konsensu. ${ }^{26}$ Typická kontinentální ústava je naopak ústava psaná, zřetelně odlišitelná od ostatních právních předpisů a mající vyšší právní sílu než obyčejné zákony. V kontinentální Evropě je nejvýznamnějším konstitucionálním prototypem ústava francouzská. Ústava První Francouzské republiky z roku 1793 vznikla na osvícenském základě v souvislosti se zrušením výsad a starého právního řádu, který byl založen na principech feudalismu. Základem tedy bylo revoluční dění, nikoli postupné historické formování. Francouzská ústava Třetí republiky se poté stala prototypem ústav, které později vznikly v kontinentální Evropě, včetně ústavy Československé republiky $\mathrm{z}$ roku $1920 .^{27}$

Odlišnosti v ústavním právu můžeme vysledovat také v představách o tom, jak má vypadat dělba moci. V Anglii byly nepochybně myšlenkové směry pragmatismu a utilitarismu těmi vůdčími vlivy, které způsobily, jaká podoba dělby moci se tam vytvořila. Stejně jako empiricky orientované anglické soudnictví, které je založeno na precedentech a dbá na tradici, rovněž v oblasti dělby moci působí ve Spojeném království tradičnější způsob rozdělení moci než na evropském kontinentu.

Historicky je již od počátku uplatňování principu dělby moci tento princip méně důsledně uplatňován v Anglii než na kontinentu. V Anglii se idea odvíjela od způsobu separace státní moci, která se objevila v době vlády Olivera Cromwella. Toto oddělení složek moci vzniklo na základě praktické potřeby, kdy docházelo k soupeření mezi armádou a parlamentem. Cromwellovi se jevilo jako nežádoucí především zasahování parlamentu do soudnictví, nicméně i přesto nepovažoval soudnictví za samostatnou složku moci, ale za součást složky výkonné. Rozlišoval pouze mezi dvěma složkami moci - zákonodárnou mocí, jíž má disponovat parlament, a výkonnou mocí, již má vykonávat protektor. ${ }^{28}$ Tento způsob rozdělení mocí Cromwell vtělil do dokumentu Instrument of Government, tedy vlastně do ústavy státu. Na rozdíl od kontinentální Evropy došel Cromwell k praktické dělbě moci čistě empiricky, bez filosofického fundamentu. Významný vliv na pozdější dělbu moci v Anglii pak mělo dílo Johna Locka Dvě pojednání o vládě,

\footnotetext{
${ }^{24}$ PETŘÍK, L. Konzervativní revoluce Margaret Thatcherové a Ronalda Reagana. Praha, 2008, s. 16-22.

${ }^{25} \mathrm{KNAPP}, \mathrm{V}$. Velké právni systémy. (Úvod do srovnávací právni vědy.), s. 94.

${ }^{26}$ BLAHOŽ, J. - BALAŠ, V. - KLÍMA, K. Srovnávaci ústavní právo. 4., přeprac. a dopl. vyd. Praha, 2011, s. 329-330.

${ }^{27} \mathrm{KNAPP}, \mathrm{V}$. Velké právni systémy. (Úvod do srovnávaci právni vědy.), s. 93.

${ }^{28}$ Cromwellova řeč z 12. záŕí 1654 a řeč z 21. dubna 1657. Dle PEŠKA, Z. Teorie rozdělení státních mocí do konce osmnáctého století. Sociologický časopis / Czech Sociological Review, 1968, č. 1, s. 29-42.
} 
publikované v roce 1690. Ani Locke ve svém díle nepředpokládal důsledné oddělení všech složek moci: ,Je téměř neproveditelné vložit síly státu do různých a sobě nepodřízených rukou nebo dáti výkonnou a federativní moc osobám, jež by mohly jednati odděleně. Tím by síla lidu byla pod různým velením, což by bylo $\mathrm{s}$ to jednoho neb druhého

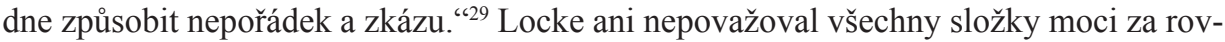
nocenné - legislativní moc je podle něj nejvyšší, ,jíž všechny ostatní jsou a musí býti podřízeny ${ }^{\text {“30. }}$ V pozdější době byla doktrína dělby moci opouštěna „ve prospěch teorie suverenity parlamentu. “31 Anglický systém má tedy blízko k tomu hierarchizovat jednotlivé složky moci, s tím, že zákonodárná složka je vysazena na nejvyšší místo. Tím se významně liší proti francouzskému systému, který vychází z principu suverenity lidu.

Ve Francii byla striktní dělba moci přímou reakcí na zneužívání moci francouzským soudnictvím před Velkou francouzskou revolucí. Před rokem 1789 francouzské soudnictví disponovalo jen málo omezovanou diskreční pravomocí a soudy byly pramálo vázány jinými hledisky než vlastní úvahou. ${ }^{32}$ Francouzské regionální vrchní soudy, známé jako les parlements, měly pravomoc nejen soudit př́ípady, ale také vydávat právní předpisy známé jako „arrêts de règlement“, které měly všeobecnou závaznost a do budoucna zavazovaly nižší soudy. Odtud pochází staré francouzské pořekadlo: „Dieu nous garde de l'équité des parlements“ („Bůh nás chrání před spravedlností soudư“). Bloisova vyhláška z května 1579 stejně jako vyhláška z dubna 1667 sice zakazovala soudcům, aby ve svém rozhodnutí uváděli jakýkoli odkaz na spravedlnost. Parlements si však pravomoc odkazovat na spravedlnost zachovaly. $Z$ výše citované francouzské gnómy lze dovozovat, že právní nejistota účastníků soudních řízení a, obecněji, adresátů právních norem byla vysoká. Velká francouzská revoluce poskytla př́ležitost to změnit. Právo mělo být např́íšě psané, mělo být psáno jednoznačným a srozumitelným jazykem, aby každý znal svá práva, a soudci neměla být ponechána možnost vytvářet všeobecně závazná pravidla chování. Výsledkem byla právní úprava nového francouzského Code Civil (1804), která v ustanovení čl. 5 soudcům zakazovala vyslovovat precedenty: „Soudcům je zakázáno, aby o věcech, které jim byly předloženy, rozhodovali obecně a normativně.“

Tento citovaný článek je formulován natolik obecně, že bývá chápán tím způsobem, že jeho působnost jde nad rámec občanského práva, a dokonce i nad rámec celého práva soukromého. Jedná se o obecnou právní zásadu kontinentálního práva, že soudce může rozhodovat toliko inter partes. V každém případě lze čl. 5 Code Civil vykládat pouze ve světle čl. 4 tohoto kodexu, nebot' ten jeho rozsah poněkud omezuje: „Soudce, který odmítne soudit pod záminkou, že zákon mlčí, že je nesrozumitelný nebo nedostatečný, může být stíhán pro odepření spravedlnosti.“"Přestože je na základě této zásady právo de iure úplné, je jím přiznána faktická existence mezer v právu a nutnost soudce tyto mezery zaplnit. K tomu také ve Francii docházelo.

${ }^{29}$ LOCKE, J. Dvě pojednání o vládě. Praha 1965, s. 210.

${ }^{30}$ Ibidem, s. 210.

${ }^{31}$ BAROŠ, J. Dělba moci jako nástroj konstitucionalismu. Jurisprudence, 2013, č. 7, s. 11-16. .

${ }^{32}$ McGONIGLE, R. The Role of Precedents in Mixed Jurisdictions: A Comparative Analysis of Louisiana and the Philippines. In Electronic Journal of Comparative Law, 2002, roč. 6.2 [online]. [cit. 2021-01-05]. Dostupné z: <http://www.ejcl.org/62/art62-1.html>. 
Srovnání francouzské a anglické historie nám tak ukazuje dva odlišné modely možnosti soudů odůvodňovat svá rozhodnutí odkazem na spravedlnost. Francouzská zkušenost vycházela $\mathrm{z}$ dlouhé konfrontace mezi parlements a monarchií v době ancien régime, což vyvrcholilo v době Velké francouzské revoluce zavedením právní úpravy polárně odlišné od úpravy anglické. ${ }^{33}$

Odlišnosti ale nalezneme i v jiných oblastech veřejného práva, např. v organizaci místní správy. Ve většině států kontinentální Evropy je místní správa založena na podřízenosti nižších článků vyšším. Britský systém je oproti tomu systémem decentralizovaným, založeným na volených úréednících, kteří nejsou podř́zeni centrálním správním úráadům. ${ }^{34}$

R. David označuje anglické a kontinentální právo za „úplný protiklad“, přičemž za rozhodující činitele vzniku této antinomie považuje dějinné příčiny, konkrétně pak dobytí Anglie Normany. Královská moc se od té doby vyvíjela v Anglii za osobitých podmínek, které jednak vtiskly jinou tváŕ feudalismu, jednak se odlišně od kontinentální Evropy vyvíjelo královské soudnictví ${ }^{35} \mathrm{~S}$ tímto konstatováním lze cum grano salis souhlasit v tom smyslu, že dobytí Anglie Normany jistě bylo zásadní ve vývoji britských ostrovů. Považovat toto ovládnutí Ostrovů za zásadní důvod odlišného vývoje oproti kontinentální Evropě ovšem považuji za velice odvážné tvrzení. Dle mého názoru je důležité poukazovat na celý komplex faktorů a mít na paměti také skutečnost, že i Normané se nepochybně museli přizpůsobovat místním ostrovním zvyklostem. Je přitom v zásadě nemožné určit, nakolik by se ubíral vývoj anglického práva jinak nebýt normanského vpádu.

R. David dále poukazuje na to, že základní skutečností, která nejvýrazněji poznamenala vývoj francouzského práva, bylo studium římského práva ve Francii. ${ }^{36}$ Evropský jev renesance studia ř́mského práva zůstal oproti tomu v Anglii jen akademickou záležitostí. Na anglických univerzitách se sice ř́mské právo přednášelo, nicméně jeho vliv byl zanedbatelný, nebot' od soudců a advokátů se v Anglii univerzitní právnické vzdělání nepožadovalo. Na rozdíl od Francie se i soudnictví vyvíjelo opačným směrem. Soudy, které aplikovaly místní obyčeje, upadly v Anglii v zapomenutí a nahradily je nové královské soudy. Ty však nepřevzaly systém založený na římském právu a vypracovaly nové právo, zvané common law. Při jeho vytváření sehrálo římské právo jen velmi omezenou úlohu. ${ }^{37}$ Dle mého soudu je možno vznik rozdílů mezi kontinentálním a anglickým pojetím skutečně nalézt $v$ odlišném dějinném vývoji. Je však otázkou, zda by se $\mathrm{v}$ př́ípadě recepce římského práva $\mathrm{v}$ Anglii vyvinul systém práva obdobný kontinentálnímu. Vždyt' rozdíly anglosaského a kontinentálního systému nejsou imanentní pouze právní kultuře, nýbrž celé sféře myšlení a projevují se nejen ve vzdálené historii, ale též nyní. V současnosti je možno poukázat na rozdíl mezi anglosaskou, dominantně analytickou, filosofií a filosofií kontinentální. Tento rozdíl zřetelně demonstruje odlišnosti ve způsobech myšlení v obou kulturách.

${ }^{33}$ PALMER, V. May God Protect Us from the Equity of Parlements: Comparative Reflections on English and French Equity Power, Tulane Law Review, 1999, č. 4, s. 1287-1308.

${ }^{34}$ BLAHOŽ, J. - BALAŠ, V. - KLÍMA, K. Srovnávaci ústavní právo, s. 338 a s. 343.

${ }^{35}$ DAVID, R. Anglické právo, s. 16.

${ }^{36}$ Ibidem, s. 13.

${ }^{37}$ Ibidem, s. 15. 


\section{Odlišnosti ve filosofii anglosaského a kontinentálního myšlení}

Mám za to, že anglosaské i kontinentální myšlení je určujícím způsobem ovládáno proudy, které jsou specifické vždy pro jejich vlastní právní kulturu. To se pokusím prokázat v tomto pojednání, které poukazuje na sice dílčí, ale zásadní rozdíl mezi současnou anglosaskou a kontinentální filosofií.

Velice aktuální je v současných akademických debatách dialog mezi analytickou (nyní často vnímanou jako primárně anglosaskou) a kontinentální filosofií. Původní analytická filosofie sice vznikla na evropském kontinentu (klasickými analytiky byli G. Frege, L. Wittgenstein a účastníci Vídeňského kruhu) a navazovala na kantovskou tradici, tato filosofie se však uchytila v anglosaském světě natolik, že dnes pojem ,analytická fillosofie“ označuje převážně kulturu či styl bádání, který je dominantní v anglosaských zemích. Používání pojmů ,analytická“ a „kontinentální“ filosofie je dnes vnímáno především jako prostředek pro zachycení odlišnosti mezi dvěma myšlenkovými kulturami. Rozdíl je vnímán na jedné straně mezi vědeckým stylem práce s důrazem na pochopení jazyka na straně analytických filosofů a na straně druhé př́iklonem k uměleckému či literárnímu stylu na straně kontinentálních fillosofů. Duchovní a literární kultura v anglosaských a kontinentálních zemích se podstatně liší, což se pak promítá také do většiny filosofických plodů v dané kultuře. I když bude kontinentální fillosof usilovat o „vědeckost“" bádání na kontinentu, jeho styl bude obvykle značně odlišný od vědeckosti analytických filosofi̊. ${ }^{38}$ Zásadní rozdíl tedy tkví ve stylu a metodě zkoumání.

Označování různých rysů za typické pro anglosaskou či kontinentální filosofii, je sice do jisté míry zobecňujícím klišé, nicméně lze se domnívat, že typické rozdíly se v dominantních proudech obou kultur skutečně vyskytují. Tyto rozdíly ve filosofii se pak také promítají do právního systému a způsobu právnického myšlení.

Analytická filosofie je primárně filosofií přesvědčení, že náš svět je světem uchopeným jazykem a pro proces zpřehlednění světa používá logickou analýzu jazyka. ${ }^{39}$ Pokud bychom chtěli porovnat blízkost stylu analytické filosofie a anglosaského právního stylu, můžeme vyjít z těchto hlavních charakteristik analytické filosofie: 1. zásadní úloha zkušenostního poznání (empirismus) a 2. důraz na logickou analýzu jazyka, určující rámec poznání.

Tradice výrazného vlivu empirismu v anglosaském světě se v právu nejvýrazněji projevuje významem precedentů a způsobem odůvodnění soudních rozhodnutí založených na common law.

Zřetelný rozdíl mezi anglosaským a kontinentálním právem se začal rýsovat již ve 12. století. Po dobytí Anglie Vilémem Dobyvatelem v roce 1066 došlo k budování jednotného práva říše. Tak vznikalo common law, které se stávalo jednotným a konzistentním také díky relevantním odkazům soudců na minulou zkušenost. Odkazy na empirii

\footnotetext{
${ }^{38}$ BERAN, O. Jazyk a individualita. Několik poznámek ke srovnání Wittgensteina s Husserlem a Heideggerem, 2008 [online]. Disertační práce. [cit. 2021-01-05]. Dostupné z: <https://is.cuni.cz/webapps/zzp/detail/25700>, s. $1-3$.

${ }^{39}$ PEREGRIN, J. Logika ve filosofii, filosofie v logice: historický úvod do analytické filosofie. Praha, 1992, s. 106.
} 
nalezneme v celém dalším vývoji anglického myšlení, počítajíce v to filosofii, sociologii či právo. „Doktríny, které se rodily na kontinentu, vycházely z rozumu, ze kterého se vyvozovaly věčné a neměnné principy chování. V Anglii byli právníci spíše empiričtí, pragmatičtí a extrovertní: se zdravým rozumem sloužili praktickým potřebám, které vyplývaly z konkrétních situací. " ${ }^{40}$ Tato tradice empirismu pokračuje i v dalších staletích a jako jeho významného představitele je možno vyzdvihnout Johna Locka, který se kriticky vymezuje vůči racionalismu a usiluje o vytvoření nové teorie poznání, vycházející ze zkušenosti. J. Locke kritizuje Descartovy vrozené ideje a důraz klade na ideje aposteriorní. ${ }^{41}$ Jak bude ukázáno $\mathrm{v}$ dalším textu, anglosaský důraz na předchozí zkušenost i význam jazyka se promítá také do způsobu odůvodnění soudů.

Akcent na důležitost jazyka je zřetelně znát v textech anglických rozsudků. Vypovídající je následující vylíčení stylu anglických soudců: „V rozhodnutí anglických soudců [...] nalezneme množství hlavních, alternativních, podpůrných a jiných argumentů, úvah právně-politických, literárních výletů za Shakespearem či Alenkou v říši divů a mnoho jiných úvah, které lze z našeho pohledu jen obtížně označit za argumenty právní. Styl je otevřená debata: soudce otevřeně vykládá všechny své argumenty v písemném odůvodnění.“42 $\mathrm{V}$ anglických rozsudcích se tak setkáváme se s množstvím argumentů a protiargumentů, se kterými se pak soudce vypořádává i za použití tzv. metody distinkce či rozlišování, na základě níž zkoumá rozdíly a míru analogie mezi různými precedenty a hledá ten, který je nejlépe aplikovatelný na posuzovaný případ. Snaží se přitom nalézat co největší počet argumentů.

Takový způsob práce je silně v opozici k právnímu stylu odůvodňování francouzskými soudy, jejichž styl je maximálně strohý; francouzští soudci neusilují o uvedení maxima argumentů a vypořádání se s nimi. Na rozdíl od mnohosti pramenů práva v Anglii je ve Francii pramenem práva zákon, na jehož ustanovení je odkazováno, tudíž konkrétní soudní rozhodnutí je pouze subsumpcí skutkových okolností pod zákonnou normu. ${ }^{43}$ Empirie a způsob argumentace zde hrají minimální roli.

Specifický způsob odůvodnění soudních rozsudků, spadající pod kontinentální systém, představuje německé právo. $V$ německém právním okruhu nalezneme obsáhlejší odůvodnění soudních rozhodnutí, než je tomu ve Francii. V germánském okruhu je také nezrrídka argumentováno nikoli pouze ustanoveními zákona, ale též právní doktrínou. Německé soudy taktéž odkazují na předchozí judikaturu, účel je ovšem odlišný od anglického právního stylu. Četnost uvádění odkazů na dřívější rozsudky nemá natolik významný vliv na závěry vlastního rozsudku, jako je tomu u anglických soudů. B. Markesinis zkomparoval některá rozhodnutí anglických a německých soudi̊ s obdobným právním problémem a dospěl k závěru, že u německých soudů „dřívější judikatura je citová-

\footnotetext{
${ }^{40}$ KRSKOVÁ A. Stát a právo v evropském myšlení, s. 278-279.

${ }^{41}$ LOCKE, J. Esej o lidském rozumu. Praha 1984, s. 38.

${ }^{42}$ BOBEK, M. O odůvodňování soudních rozhodnutí. Právní rozhledy, 2010, č. 6, s. 204-211.

${ }^{43}$ Pro úplnost je nutno dodat, že dnes již není možné francouzské soudcovské právo popsat ,jen optikou nesmirně krátkého odůvodněni soudního rozhodnutí. Spíše lze hovořit o pluralitě právního diskursu. " In GERLOCH, A. - KYSELA, J. - KÜHN, Z. - WINTR, J. - TRYZNA, J. - MARŠÁLEK, P. - BERAN, K. Teorie a praxe tvorby práva. Praha, 2008, s. 89.
} 
na bud' jako pouhá ilustrace určitého pohledu nebo jako prŕílad zavedené praxe. Zrrídka, pokud vůbec, je tato judikatura zkoumána způsobem, kterým by anglický soud posoudil a předefinoval dřívější rozhodovací právo. Existují tedy jen malé nebo žádné doklady o tom, že předchozí případy byly použity jako stavební kameny pro nové rozhodnutí. “"44 Ve prospěch poznatku, že kontinentální styl je oproti anglosaskému stylu relativně dobře vymezitelný, svědčí také skutečnost, že i pro německého soudce je hlavním stavebním kamenem jeho rozhodnutí použitelný zákon, následovaný akademickou exegezí, které byla tato právní úprava podrobena.

Ovšem nejen styl práce s common law ukazuje na specifický anglosaský styl odůvodnění. Důraz na jazyk lze v anglosaském právu hledat také ve způsobu interpretace zákonných pravidel. Zákonná pravidla se v Anglii používají pro rozšiření, zrušení (overruling) nebo změnu existujících pravidel common law. Zákonem mohou být rovněž vytvořena zcela nová pravidla. Nutno připomenout, že zákony jsou v Anglii tradičně formulovány mnohem kazuističtěji než na kontinentu.

Výklad zákona v Anglii je tradičně veden třemi interpretačními pravidly, kterým jsou literal rule (doslovné pravidlo), golden rule (zlaté pravidlo) a mischief rule (pravidlo vady). ${ }^{45}$ Doslovné pravidlo má přednost před ostatními a je právě tím, které demonstruje, že jazyk je východiskem pro interpretaci anglických zákonů. Soudci podle tohoto vodítka musí spoléhat na přesné znění zákona a veškerá slova v zákoně musí být interpretována podle toho, co přesně znamenají, i kdyby se tímto výkladem dospělo k absurdnímu či nespravedlivému závěru.

Za zásadní precedens, v němž bylo doslovné pravidlo vyloženo, je uznáván text anglického soudce Tindala CJ v rozsudku Sussex Peerage Case (1844): „Jediným pravidlem pro pochopení zákonů Parlamentu je, že by měly být vykládány v souladu se záměrem Parlamentu, který zákon přijal. Pokud jsou slova zákona sama o sobě přesná a jednoznačná, pak není potřeba nic jiného, než tato slova vysvětlit $v$ tomto přirozeném a běžném smyslu. Samotná slova v takovém př́ípadě nejlépe deklarují záměr zákonodárce.“46

Doslovné pravidlo je z ústavního hlediska založeno na doktríně suverenity Parlamentu, nebot' z ní vyplývá kromě jiného také to, že zákon může být vydán pouze Parlamentem a že Parlament má právo vydat jakýkoli zákon bez ohledu na to, jak absurdně může takový zákon znít. Existence tohoto pravidla přispívá k právní jistotě, nicméně je pravdou, že rigidní uplatňování tohoto pravidla může jako nezamýšlený důsledek vést k podvrácení záměru zákonodárce. Nebere také v úvahu limitaci jazyka, redukujícího skutečnost.

Příklad praktického použití doslovného výkladu, které ukazuje natolik silné lpění na textu zákona, že vede $\mathrm{k}$ absurdnímu závěru, nalezneme $\mathrm{v}$ soudním prrípadu $R v$ Harris (1836). ${ }^{47}$ Př́slušný zákon stanovil, že se jedná o porušení zákona, pokud je někdo „,bodnut,

${ }^{44}$ MARKESINIS, B. Judicial Style and Judicial Reasoning in England and Germany. The Cambridge Law Journal, 2000, č. 2, s. 294-309.

${ }^{45}$ GILLESPIE, A. The English Legal System. Oxford, 2007, s. 36-40.

${ }^{46}$ Sussex Peerage Case (1844) $11 \mathrm{Cl} \&$ Fin 85.

${ }^{47} R v$ Harris (1836) $7 \mathrm{C} \& \mathrm{P} 446$. 
říznut či zraněn “ jinou osobou. Pachatel ve rvačce kousl obět' do nosu a poté ještě policistu do prstu. Nebyl ovšem shledán vinným, a to na základě toho, že slova v zákoně odkazovala na použití nástroje či zbraně, přičemž zuby nejsou za nástroj či zbraň považovány.

Doslovné pravidlo je často kritizováno, když je jeho aplikací dosaženo absurdních výsledků, jako v uvedeném prípadě $R v$ Harris. Pokud by však toto pravidlo neexistovalo, pak by soudy měly pravomoc volně vykládat každý zákon Parlamentu, čímž by přepisovaly vůli Parlamentu. Na takovém způsobu fungování není anglický právní systém založen.

Aby se minimalizovalo riziko výkladů, které vedou k absurdnímu závěru, vyvinulo se jako záloha doslovného pravidla zlaté pravidlo. Podle něj platí, že pokud doslovný výklad vede $\mathrm{k}$ absurditě, má čtenár dané slovo číst v kontextu věty jako celku a posoudit, o co se Parlament snažil při psaní textu zákona. W. Blackstone vysvětlil, kdy by se soudy měly od přesného textu odchýlit, tímto způsobem: „Co se týče účinků a důsledků, platí pravidlo, že tam, kde slova nemají bud' žádný, nebo velmi absurdní význam, pokud jsou chápána doslovně, musíme se trochu odchýlit od jejich obecně přijímaného smyslu. “"48 Zlaté pravidlo je při bližším zkoumání méně explicitní formou třetího pravidla, pravidla vady. ${ }^{49}$ Aplikace pravidla vady se používá $\mathrm{k}$ intepretaci zákona tehdy, pokud byl tento zákon prrijat, aby napravil mezeru (vadu) common law. Soudy podle tohoto pravidla posuzují, jakou vadu měl zákon napravit, a přitom jdou nad rámec slov zákona, když zjišt'ují mezeru, kterou měl zákon zacelit. Styl odůvodnění však zůstává specifický pro anglosaský styl a liší se od kontinentálního pojetí. Je také typické, že pravidla pro interpretaci zákonů byla v Anglii vytvořena právě soudci.

Vzhledem k tomu, že anglické právo si v zásadě zachovalo kazuistickou povahu a masa právních pravidel nebyla nikdy uspořádána do kodexu, tvorba práva se odehrávala př́pad od př́ípadu poznávanou realitou. Anglosaská teorie byla tedy soustředěna na analýzu jazyka, jejíž projevy se odrážejí v argumentaci a diskusích soudců, advokátů, právních učenců i zákonodárců. ${ }^{50}$

Uvádění mnohosti argumentů při práci s common law je přitom pro odůvodnění anglických soudů příznačné, zároveň však lze i v časové perspektivě zaznamenat patrné změny. S narůstajícím počtem významných zákonů a nařízení ve Spojeném království roste význam interpretace zákonů oproti common law, což je faktor přispívající ke konvergenci s kontinentálním systémem.

\section{Interpretace normativních právních aktů evropských právních kultur v historickém komparativním pohledu}

K analýze podobností a odlišností metod interpretace zákona z diachronního hlediska je uváděno, že až do konce 18 . století si byly principy výkladu zákona podobné. Relativ-

\footnotetext{
${ }^{48}$ BLACKSTONE, W. - LEMMINGS, D. The Oxford Edition of Blackstone's Commentaries on the Laws of England. Book I: Of the Rights of Persons. Oxford, 2016, s. 46-47.

${ }^{49}$ THE LAW COMMISSION AND THE SCOTTISH LAW COMMISSION (LAW COM. No. 21) (SCOT. LAW COM. No. 11). The Interpretation of Statutes. London, 1969, s. 19.

${ }^{50}$ KRSKOVÁ, A. Stát a právo v evropském myšlení, s. 278-279.
} 
ní jednota evropské doktríny zákonného výkladu se rozpadla až po přijetí velkých kodifikací. Komparatista S. Vogenauer uvádí, že to nebylo nezbytně způsobeno dílčí omezenou kodifikací určitých pravidel výkladu na kontinentu (jako jsou §§ 46-49 Úvodu k pruskému kodexu Allgemeines Landrecht für die Preußischen Staaten, čl. 4 a 5 francouzského Code civil a $\S \S 6-9$ rakouského zákoníku Allgemeines Bürgerliches Gesetzbuch), ale vliv přikládá především nacionalizaci právní nauky. Římské právo sice nebylo úplně zapomenuto, ale v národních státech se vyvinuly vlastní taxonomie a metody výkladu. Francouzská doktrína si zachovala dichotomii „gramatické“ a „logické“ interpretace. ${ }^{51} \mathrm{~V}$ Německu byl způsob výkladu postupně nahrazován kategorizací zavedenou zakladatelem historickoprávní školy Friedrichem Carlem von Savignym, který rozlišovat metodu výkladu „gramatickou“, „historickou“, „systematickou“ a „logickou“. $\mathrm{K}$ možnostem pátrat po rozdílech ve výkladu právních předpisů v různých státech či právních kulturách, je však vhodné mít na paměti tezi J. Wintra: že ,je-li [...] primárním objektem interpretace práva normativní text, je zřejmé, a dějiny evropského právního myšlení to dokládají, že možnosti interpreta uchopovat normativní obsah právního předpisu jsou omezené, a že tedy i okruh základních interpretačních metod bude úzký. "“52 V samotné metodice výkladu textu zákonů najdeme období, kdy je anglosaské právo blíže kontinentálnímu, i období, kdy se jejich metody značně liší. Gramatická metoda výkladu je nepochybně podobná tzv. doslovnému pravidlu v anglosaské doktríně. Rovněž systematická metoda výkladu je nejen běžnou interpretační metodou ve všech jurisdikcích, které prrijaly Savignyho kategorizaci, ale prvky podobnosti s ní nalezneme také v tzv. zlatém pravidle užívaném v anglosaských zemích. ${ }^{53}$

Německá právní metodologie si ovšem oproti Francii rovněž přisvojila ještě další fundamentální odlišnost, kterou poprvé navrhl Savigny, a to přísné koncepční oddělení „zákonného výkladu“ a „dalšího vývoje práva“ (což je eufemismus pro tvorbu soudního práva). Toto rozlišení se ve Francii nikdy nezvýraznilo. Pro anglické a německé právníky je silně iritující, že Soudní dvůr Evropské unie (dále jen SDEU) přijal francouzskou terminologii a tvrdí, že ,interpretuje“ právo EU, ačkoli se zjevně podílí na tvorbě soudního práva. ${ }^{54}$

V tomto ohledu je vhodné připomenout, že i v kontinentálních právních ráádech je přiznávána čím dál větší role ustálené judikatuře, přestože nemá precedenční charakter. Český Nejvyšší soud např́klad judikoval, že „i když právní názory, které Nejvyšší soud České republiky zaujal v jiných právních věcech, nejsou ex lege právně závazné (apliko-

${ }^{51}$ VOGENAUER, S. Interpretation of Statutes, History of, s. 986-990. S. 989. In: BASEDOW, J. - HOPT, K. J. - ZIMMERMANN, R. - STIER, A. (eds.) The Max Planck Encyclopaedia of European Private Law. Vol. II. Oxford, 2012.

${ }^{52}$ WINTR, J. Metody a zásady interpretace práva. Praha, 2013, s.18.

${ }^{53}$ Srov. rozhodnutí Grey v Pearson (1857) 6 hl Cas 61, 106; 10er 1216, 1234: „Při vytváření zákonů i při vytváření všech ostatních písemných právních dokumentů je nutné dbát na gramatický a obvyklý význam slov, ledaže by to vedlo $\mathrm{k}$ absurditě nebo rozporu se zbytkem právního dokumentu, $\mathrm{v}$ kterémžto př́ípadě lze modifikovat gramatický a běžný význam slov tak, aby se předešlo této absurditě nebo rozporu, ale nic dalšího" (zvýraznění přidáno autorem).

${ }^{54}$ VOGENAUER, S. Interpretation of Statutes, s. 989. 
vatelné) na případy s obdobným skutkovým či právním základem, z nějž vzešel ten který judikát dovolacího soudu, nelze však současně ztrácet ze zřetele, že došlo-li v soudní rozhodovací praxi při řešení určité materie $\mathrm{k}$ judikatornímu ustálení právního názoru, je z povahy věci nezbytné, aby soudy nižších stupňů tento judikatorní posun ve své rozhodovací praxi reflektovaly a v př́padě, že takový právní názor nesdílejí, jej ve světle jimi pečlivě vyložené argumentace (kriticky) konfrontovaly a seznatelným způsobem (v odůvodnění písemného vyhotovení svého rozhodnutí) vyložily, proč, resp. z jakého (jakých) nosného (nosných) důvodu (důvodů) nebylo lze se ve věci s obdobným skutkovým či právním základem s předmětným judikátem ztotožnit.“"55 Obdobně se vyjadřují i jiné vyšší soudy, přičemž se odkazují i na principy právního státu a zákaz jurisdikční libovůle. V praxi tedy nelze konstatovat absolutní absenci normativity vybraných (zvláště těch publikovaných) soudních rozhodnutí vyšších soudů v kontinentálním právu. Nelze ovšem konstatovat ani absolutní závaznost precedentu v common law. Z. Kühn príhodně připomíná, že v zemích common law soudy obcházejí princip stare decisis využitím institutu distinctions (odlišení) nebo zužováním rozsahu rationis decidendi jako jediné formálně závazné části rozhodnutí. ${ }^{56}$ Lze souhlasit s pojetím, podle něhož se kontinentální soud může odchýlit od judikatury vyšších soudů tehdy, pokud takové odchýlení přesvědčivě odůvodní..$^{57}$ To jej přibližuje anglosaské praxi.

Navzdory tomu, že se vyvinuly rozdílné terminologie a kategorizace v národních teoriích výkladu normativních právních aktů, vyskytla se v 19. a 20. století v metodách interpretace práva i řada společných evropských trendů.

Až do konce 18. století na celém kontinentu převládal poměrně liberální přístup k výkladu zákona. Soudnictví požívalo pravomoc odchýlit se od doslovného smyslu zákonů prostřednictvím „extenzivních“ nebo „restriktivních“ interpretací. Ke konci 18. století a dále v 19. století přijaly kontinentální právní rády metodu výkladu mnohem více založenou na textu. Tento přístup byl označen jako ,exegetická škola“ a přinesl rozpor s dřívějšími metodami výkladu. ${ }^{58} \mathrm{Na}$ něj navázal kontinentální právní pozitivismus, jenž vznikl později než právní pozitivismus anglický a měl ovšem také jiné kořeny.

Trendy, které se projevily jak v Anglii, tak v kontinentální Evropě, můžeme vypozorovat také $\mathrm{v}$ příslušných právních směrech respektujících liberálnější a teleologičtější výklad zákona, který je otevřený vůči hodnotícím a normativním úvahám, včetně argumentů o spravedlnosti, přiměřenosti a spravedlnosti. Podle Vogenauera se v kontinentální Evropě tento obnovený důraz na účelové uvažování a politické argumenty objevil $\mathrm{v}$ poslední čtvrtině 19. století, zatímco v Anglii byl opětovně přijat až ve druhé polovině 20. století. Vogenauer je toho názoru, že jako výsledek popsaného jevu dnes panuje v interpretační praxi např́čc evropskými právními systémy zásadní jednota, a to navzdory převládajícím rozdílům v klasifikaci a terminologii, které se objevují v národní literatuře

\footnotetext{
${ }^{55}$ Rozsudek Nejvyššího soudu České republiky ze dne 3. 12. 2009, sp. zn. 30 Cdo 2811/2007.

${ }^{56} \mathrm{KÜHN}, \mathrm{Z}$. - BOBEK, M. - POLČÁK, R. (eds.) Judikatura a právní argumentace: teoretické a praktické aspekty práce s judikaturou. Praha, 2006, s. 7.

${ }^{57}$ Ibidem, s. 11.

${ }^{58}$ VOGENAUER, S. Interpretation of Statutes, s. 989.
} 
o zákonném výkladu. ${ }^{59}$ Silnou roli v přiblížení analyzovaných typů právní kultury můžeme nepochybně přiznat přijetí zákona o lidských právech z roku 1998 a členství Spojeného království v EU.

Vzhledem k množství a důležitosti harmonizačních předpisů, jejichž původcem je EU, byly způsoby výkladu práva výrazně poznamenány činností SDEU. SDEU často používá teleologickou metodu výkladu, což se projevuje i v interpretaci daných pravidel národními soudci. H. Rösler považuje stručnost a deduktivnost odůvodnění SDEU, vyplývající z vlivu francouzského Conseil d'Etat na styl výkladu právních předpisů, za příčinu toho, proč je SDEU omezen v tom, aby přispěl k právní teorii a systematickému rozvoji evropského soukromého práva. Apodiktická a sebereferenční povaha rozsudků přitom do značné míry vyplývá z povahy SDEU jakožto mezinárodního panelu soudců, kteří musí sladit různé právní kultury a jazyky. ${ }^{60}$

Z toho vyplývá, že přistup zaměřený na výklad gramatického kontextu a analýzu běžného jazyka práva EU musí být nutně omezen. Z tohoto důvodu SDEU často významným způsobem používá účelové úvahy, což je př́stup, který se neuplatňuje pouze u řešení sporů způsobených odlišnými verzemi textů. Tato metoda je používána $\mathrm{z}$ hlediska funkční perspektivy EU tak, aby bylo vyhověno snaze dosáhnout cílů stanovených v primárním právu, jako je vytvoření společného trhu. Jedná se ovšem o styl výkladu, který je původní tradici výkladu práva v anglosaské právní kultuře dosti vzdálen.

V rozsudcích SDEU existuje relativně jen velmi málo zmínek vycházejících z komparace institutů $\mathrm{v}$ různých právních řádech EU. Odkazy na právní systémy členských států lze častěji nalézt ve stanoviscích generálního advokáta. Nedostatek odkazů na srovnávací právo v rozsudcích SDEU se může zdát poněkud překvapivý vzhledem $\mathrm{k}$ tomu, že sekundární právo EU je často založeno na výsledku komparace právních řádů členských států EU. Zdá se také přirozené předpokládat, že skupina složená ze soudců z různých právních systémů by tento nástroj mohla dobře využít. Srovnávací úvahy však nejsou výslovně zahrnuty do rozsudků proto, aby se zabránilo narušení autonomních právních textů EU, $\mathrm{k}$ němuž by mohlo dojít odkazováním na konkrétní právní řády členských států. ${ }^{61}$

Použití komparativní metody nicméně musí hrát roli při vyplňování mezer v právu a rozvoji obecných zásad právních. SDEU tak učinil např́klad tehdy, když vysvětlil odpovědnost státu s odkazem na obecné právní zásady, které existují v mezinárodním právu a je možno je nalézt ve všech členských státech EU. ${ }^{62}$

Vliv kontinentálních směrů na Spojené království prostřednictvím judikatury SDEU ovšem nebyl jednostranný. Spolu se vstupem Spojeného království do Evropských společenství se také projevil vliv anglického práva na komunitární právo, potažmo na právní

\footnotetext{
${ }^{59}$ Ibidem, s. 989-990.

${ }^{60}$ RÖSLER, H. Interpretation of EU Law, s. 979-982. S. 979. In: BASEDOW, J. - HOPT, K. J. ZIMMERMANN, R. - STIER, A. (eds.) The Max Planck Encyclopaedia of European Private Law. Vol. II. Oxford, 2012.

${ }^{61}$ Ibidem, s. 979.

${ }^{62}$ Rozsudek Soudního dvora ze dne 5. března 1996. Brasserie du Pêcheur SA proti Bundesrepublik Deutschland a The Queen proti Secretary of State for Transport, ex parte: Factortame Ltd a dalši. Spojené věci C-46/93 a C-48/93. In Sbírka soudních rozhodnutí. 1996, s. I-1029, body 29 a násl.
} 
řády kontinentální Evropy (např. po vstupu Británie do EU předchůdce SDEU připustil ústní argumentaci, došlo ke zvýšení množství odkazů SDEU na předchozí judikaturu ad.).

Lze tedy nepochybně konstatovat, že SDEU přispěl k přiblížení anglosaského a kontinentálního typu právní kultury. Rovněž z historického hlediska došlo ke konvergenci, je však nutné podotknout, že ve Spojeném království stále přetrvává význam common law, práce $\mathrm{s}$ judikaturou je jiná než v pevninské Evropě a význam zákona je zřetelně nižší než na kontinentu.

\section{Závěr}

V př́spěvku bylo prezentováno, že anglosaský i kontinentální systém jsou dvěma samostatnými systémy právní kultury, které se však vyvíjejí v rámci jedné křest’ansko-židovské civilizace, kterou je možno vymezit oproti jiným civilizacím, jako je např́íklad civilizace islámská. Bylo demonstrováno, že při praktické komparaci je nutno podobnost či rozdílnost jednotlivých systémových znaků vždy vztahovat vůči nějakému celku, tj. musí zde existovat sociálně právní soustava jakožto společný referenční systém. Jednotlivé systémové prvky mohou být porovnány toliko tehdy, splňují-li princip racionální komparability.

Na uvedených př́kladech i na rozdílném historickém vývoji bylo doloženo, že historicky vzniklé odlišnosti mezi sledovanými právními kulturami se týkají jak práva veřejného, tak práva soukromého (srov. např. rozdílnou koncepci dělby moci, nechut' k oddělování veřejného a soukromého práva ve Spojeném království, výlučnost psané normy na evropské pevnině oproti nepsanému právu, z něhož vychází anglická doktrína). Dříve byl výzkum zaměřen pouze na soukromé právo, dnes je ale zřejmé, že rozdíly jsou rozeznatelné také v oblasti veřejného práva. Rovněž prokazatelnost napojení právní kultury na obecné filosofické myšlení svědčí o správnosti hypotézy, že odlišnost mezi anglosaským a kontinentálním systémem právní kultury lze identifikovat nejen v soukromém, ale též ve veřejném právu.

Zakotvení právní kultury v obecné kultuře a zároveň odlišnost sledovaných právních kultur jsou v prŕspěvku demonstrovány prostřednictvím vědeckého sváru mezi analytickou filosofií anglosaského střihu a kontinentální filosofií. Je ukázáno, že hlavní znaky analytické filosofie, jako je empirismus a důraz na logickou analýzu jazyka, je možno najít v doktrínách anglosaské intepretace práva. Vlivem globalizace, konsensu na společné institucionální ochraně lidských práv, společném členství v mezinárodních či nadnárodních institucích ovšem i přes značné rozdíly došlo k tomu, že ke konvergenci došlo také v oblasti způsobu interpretace práva. Přetrvávající odlišnosti v systému common law však svědčí o tom, že je smysluplné sledované systémy od sebe nadále odlišovat.

\section{Literatúra}

ADAMOVÁ, Karolina, Petr BĚLOVSKÝ, David FALADA, et al. Dějiny evropského kontinentálního práva: vysokoškolská právnická učebnice. 3. uprav. vyd. Praha : Leges, 2010. ISBN 978-80-87212-54-7 
ARISTOTELÉS. Politika. 2. vyd. Praha : Petr Rezek, 1998. ISBN 80-86027-10-4

ARISTOTELÉS, KREJČÍ, František, ed. Aristotelova Metafysika. Praha : Česká akademie věd a umění, 1927

ÁRNASON, Jóhann Páll. Civilizations in dispute: historical questions and theoretical traditions. Leiden : Brill, 2003. ISBN 90-04-13282-1

ÁRNASON, Jóhann Páll. Civilizační analýza: Evropa a Asie opět na rozcestí. Praha : Filosofia, 2009. ISBN 978-80-7007-307-0

ÁRNASON, Jóhann Páll. Max Weber jako klasik civilizační analýzy: komparativní pohledy na souhru kultury a moci. Sociológia, 2012, roč. 44, č. 5

BAROŠ, Jiří. Dělba moci jako nástroj konstitucionalismu. Jurisprudence, 2013, roč. 2013, č. 7, s. 11-16. ISSN 1802-3843

BASEDOW, Jürgen, Klaus J. HOPT, Reinhard ZIMMERMANN, Andreas STIER, ed. The Max Planck Encyclopaedia of European Private Law, Vol. II. Oxford: Oxford University Press, 2012. ISBN 9780199578955

BERAN, Ondřej. Jazyk a individualita. Několik poznámek ke srovnání Wittgensteina s Husserlem a Heideggerem, 2008 [online]. Disertační práce. [cit. 2021-01-05]. Dostupné z: $<$ https://is.cuni.cz/webapps/zzp/detail/25700>

BLACKSTONE, William; LEMMINGS, David. The Oxford Edition of Blackstone's Commentaries on the Laws of England. Book I: Of the Rights of Persons. Oxford: Oxford University Press, 2016. ISBN 9780198768975

BLAHOŽ, Josef, Vladimír BALAŠ a Karel KLÍMA. Srovnávací ústavní právo. 4., přeprac. a dopl. vyd. Praha : Wolters Kluwer ČR, 2011. ISBN 9 978-80-7357-629-5

BOBEK, Michal. O odůvodňování soudních rozhodnutí. Právní rozhledy, 2010, roč. 18, č. 6. s. 204-211. ISSN 1210-6410

CRUZ, Peter de. Comparative law in a changing world. 2nd ed. London: Cavendish Publishing, 1999. ISBN 1-85941-432-X

DAVID, René. Anglické právo. Bratislava : Vydavatel'stvo Slovenskej akadémie vied, 1972

GERLOCH, Aleš a Pavel MARŠÁLEK, ed. Zákon v kontinentálním právu: sborník příspěvků z mezinárodní vědecké konference „Místo a úloha zákona v kontinentálním typu právní kultury: tradice, současnost a vývojové tendence“ (Praha 27.-28. května 2004). Praha : Eurolex Bohemia, 2005. ISBN 80-86861-06-6

GERLOCH, Aleš, Jan KYSELA, Zdeněk KÜHN, Jan WINTR, Jan TRYZNA, Pavel MARŠÁLEK a Karel BERAN. Teorie a praxe tvorby práva. Praha : ASPI, 2008. ISBN 978-80-7357-362-1

GILLESPIE, Alisdair. The English Legal System. Oxford : Oxford University Press, 2007. ISBN 9780199281343

KNAPP, Viktor. Velké právní systémy: úvod do srovnávací právní vědy. Praha : C. H. Beck, 1996. ISBN 807179-089-3

KRSKOVÁ, Alexandra. Stát a právo v evropském myšlení. 2. vyd. Praha : Eurolex Bohemia, 2005. ISBN 80$86861-15-5$

KUKLÍK, Jan a Radim SELTENREICH. Dějiny angloamerického práva. 2. vyd. Praha : Leges, 2011. ISBN 978-80-87212-87-5

KÜHN, Zdeněk, Michal BOBEK a Radim POLČÁK, ed. Judikatura a právní argumentace: teoretické a praktické aspekty práce s judikaturou. Praha : Auditorium, 2006. ISBN 80-903786-0-9

LINHART, Jiří, Alena VODÁKOVÁ a Miloslav PETRUSEK, ed. Velký sociologický slovník. Praha : Karolinum, 1996. ISBN 80-7184-311-3

LOCKE, John. Dvě pojednání o vládě. Praha : Nakladatelství Československé akademie věd, 1965

LOCKE, John. Esej o lidském rozumu. Praha : Svoboda, 1984

MARKESINIS, Basil. Judicial Style and Judicial Reasoning in England and Germany. The Cambridge Law Journal, 2000, Vol. 59, No. 2, s. 294-309. ISSN 0008-1973

McGONIGLE, R. The Role of Precedents in Mixed Jurisdictions: A Comparative Analysis of Louisiana and the Philippines. In Electronic Journal of Comparative Law, 2002, Vol. 6.2 [online]. [cit. 2021-01-05]. Dostupné z $<$ http://www.ejcl.org/62/art62-1.html>

MONTESQUIEU, Charles Louis de Secondat. O duchu zákonů. Dobrá Voda : Aleš Čeněk, 2003. ISBN 8086473-30-9

PALMER, V. May God Protect Us from the Equity of Parlements : Comparative Reflections on English and French Equity Power, Tulane Law Review, 1999, Vol. 73, No. 4 
PEREGRIN, Jaroslav. Logika ve filosofii, filosofie v logice: historický úvod do analytické filosofie. Praha : Herrmann, 1992

PEŠKA, Zdeněk. Teorie rozdělení státních mocí do konce osmnáctého století. Sociologický časopis / Czech Sociological Review, 1968, roč. 4, č. 1, s. 29-42. ISSN 0038-0288

PETŘÍK, Lukáš. Konzervativní revoluce Margaret Thatcherové a Ronalda Reagana. Brno : Centrum pro studium demokracie a kultury (CDK), 2008. Politika a společnost. ISBN 978-80-7325-167-3

TSCHENTSCHER, A. Dialektische Rechtsvergleichung - Zur Methode der Komparistik im öffentlichen Recht. Juristen Zeitung, 2007, Jhrg. 62, Nr. 17, s. 807-816. ISSN 0022-6882

STÖRIG, Hans Joachim. Malé dějiny filozofie. Praha : ZVON, Vyšehrad, 1999. ISBN 80-7113-236-5

ŠTEFANOVIČ, Milan. Všeobecná porovnávacia právoveda. Bratislava : Univerzita Komenského, 1992. ISBN 80-7160-024-5

THE LAW COMMISSION AND THE SCOTTISH LAW COMMISSION (LAW COM. No. 21) (SCOT. LAW COM. No. 11). The Interpretation of Statutes. London : H. M. Stationery Office, 1969. ISBN 0102256691

WINTR, Jan. Metody a zásady interpretace práva. Praha : Auditorium, 2013. ISBN 978-80-87284-36-0

ZWEIGERT, K. - KÖTZ, H. Einführung in die Rechtsvergleichung. Band 1: Grundlagen. 3. Auflage. Tübingen 1992. ISBN 3161465482 